\title{
DÜBLIN
}

Technological University Dublin

ARROW@TU Dublin

\section{Assessing the Market Niche of Eurasian Rail Freight in the Belt and Road Era.}

\author{
Xu Zhang \\ Technological University Dublin, xu.zhang@tudublin.ie \\ Hans-Joachim Schramm \\ Vienna University of Economics and Business Administration
}

Follow this and additional works at: https://arrow.tudublin.ie/beschspart

Part of the Business Commons

\section{Recommended Citation}

Zhang, X. and Schramm, H.-.J. (2020). Assessing the market niche of Eurasian rail freight in the belt and road era. International Journal of Logistics Management, volume ahead-of-print. doi:10.1108/ IJLM-12-2019-0351

This Article is brought to you for free and open access by the School of Transport Engineering, Environment and Planning at ARROW@TU Dublin. It has been accepted for inclusion in Articles by an authorized administrator of ARROW@TU Dublin. For more information, please contact arrow.admin@tudublin.ie, aisling.coyne@tudublin.ie,gerard.connolly@tudublin.ie.

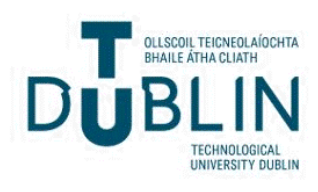




\section{International Journal of Logistics Manag}

\section{Assessing the Market Niche of Eurasian Rail Freight in the Belt and Road Era}

\begin{tabular}{|r|l|}
\hline Journal: & International Journal of Logistics Management \\
\hline Manuscript ID & IJLM-12-2019-0351.R2 \\
\hline Manuscript Type: & Original Article \\
\hline Keywords: & $\begin{array}{l}\text { Global logistics, Logistics cost, Logistics services, Logistics strategy, } \\
\text { Maritime logistics, Agile }\end{array}$ \\
\hline Research Method: & Modelling \\
\hline Geography: & Europe, China \\
\hline
\end{tabular}

\section{SCHOLARONE ${ }^{m}$ \\ Manuscripts}

To be cited as:

Zhang, X., Schramm, H.-J. (2020) Assessing the Market Niche of Eurasian Rail Freight in the Belt and Road Era, International Journal of Logistics Management, [accepted manuscript] DOI 10.1108/IJLM-12-2019-0351 


\title{
Assessing the Market Niche of Eurasian Rail Freight in the Belt and Road Era
}

\begin{abstract}
Purpose

This paper presents an overview of the recent development of Eurasian rail freight in the Belt and Road era and further evaluates its service quality in terms of transit times and transport costs compared to other transport modes in containerised supply chains between Europe and China.

\section{Design/methodology/approach}

A trade-off model of transit time and transport costs based on quantitative data from primary and secondary sources is developed to demonstrate the market niche for Eurasian rail freight vis-a-vis the more established modes of transport of sea, air, and sea/air. In a scenario analysis, further cargo attributes influencing modal choice are employed to show for which cargo type Eurasian rail freight service is favourable from a shipper's point of view.
\end{abstract}

\section{Findings}

At present, Eurasian rail freight is about $80 \%$ less expensive than air freight with only half of the transit time of conventional sea freight. Our scenario analysis further suggests that for shipping time-sensitive goods with lower cargo value ranging from $1.23 \mathrm{USD} / \mathrm{kg}$ to 10.89 $\mathrm{USD} / \mathrm{kg}$ as well as goods with lower time sensitivity and higher value in a range of 2.46 $\mathrm{USD} / \mathrm{kg}$ to $21.78 \mathrm{USD} / \mathrm{kg}$, total logistics costs of Eurasian rail freight service rail is cheaper than all other modes of transport.

\section{Practical implications}

As an emerging competitive solution, Eurasian rail freight demonstrates to be an option beneficial in terms of transport cost, transit time, reliability and service availability, which offers a cost-efficient option enabling shippers to build up agile and more sustainable supply chains between China and Europe.

\section{Original/value}

Our study firstly provides a comprehensive assessment of present Eurasian rail freight including a thorough comparison with alternative modes of transport from a shipper's point of view.

\section{Keywords}

Belt and Road Initiative, Eurasian Land Bridge; Trans-Siberian Railway; container block train; service quality; transport cost; transit time; cargo value; value to weight ratio. 


\section{Introduction}

In 2013, the term 'Belt and Road' first came into the spotlight as China's masterplan initiative to revive the Ancient Silk Road was announced by Chinese President Xi Jinping. Following the National Development and Reform Commission (NDRC) (2015), the now called 'Belt and Road Initiative' (BRI) is often communicated as a "National Vision" and "Foreign Strategy" towards regional cooperation, and it is also mentioned about infrastructural project construction and investments (van der Leer and Yau, 2016).

The BRI includes two major parts - the New Silk Road Economic Belt and the 21st-Century Maritime Silk Road (hereinafter referred to as the Belt and the Road respectively). Both represent a network of ports, railways, roads, pipelines, and utility grids connecting China with Central Asia, West Asia, and parts of South Asia, Europe, and Africa (NDRC, 2015; Tian, 2016). Although the BRI is more than just physical connections (Tian, 2016), it provides a blueprint framework for Chinese diplomatic, commercial, and foreign infrastructure policies to get access to new markets for trade and investments (van der Putten and Meijnders, 2015). The aims of the BRI are to (1) promote connectivity of Asian, European and African continents via land, sea, and air, (2) establish and strengthen regional cooperation and partnerships among the countries along these routes, and (3) facilitate the flow of economic resources and integration of markets (Song, 2015).

The Belt part of BRI revives the Ancient Silk Road as a land route for trading between the East and the West - not by camel or donkey but by railway (Otsuka, 2001), and goods remain in the same container for the entire intermodal journey (Rodrigue, 2017). Currently, the Eurasian rail freight only takes a small share of the total transport volume between China and Europe (Bucsky, 2019). However, with the rapid growth of freight transport on the rail routes along the Belt, the Ancient Silk Road trading routes are coming back to life again as container block trains have emerged as an alternative transport mode there in recent years (see Figure 1). In 2019, it is reported that there are 8,225 container block trains with 725,000 TEU transported on the Belt (MOFCOM, 2020).

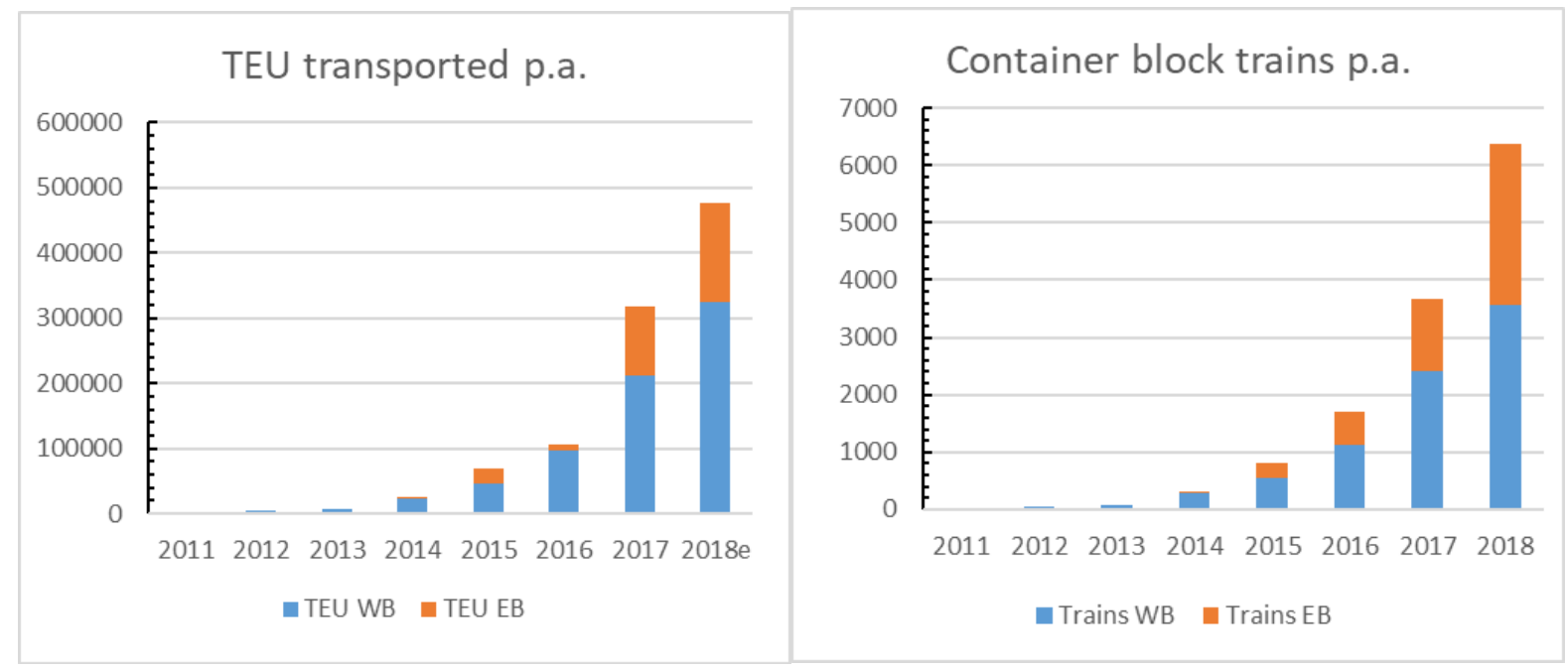

Figure 1: China-Europe rail freight continues to soar Source: CRCT (2019), Modor Intelligence (2019), Zhang (2019) 
In response to the emergence of Eurasian rail freight, most research studies on Eurasian rail freight and the BRI are policy studies or consultancy work (Davydenko et al., 2012; UNECE, 2012, 2017; Rastogi and Arvis, 2014; Ardunio, 2016; Galushko, 2016; UIC and Roland Berger, 2017; Jakóbowski et al., 2018; Vinokurov et al., 2018). In addition to this, a rapidly increasing number of scholarly contributions deal with the competitiveness of container block train operations between China and Europe like Rodemann and Templar (2014), Besharati et al. (2017), Chen et al. (2017), Seo et al. (2017), Yang et al. (2017, 2018), Wiegmans and Janis (2018), Jiang et al. (2018, 2019), Wen et al. (2019), Bucsky (2019), Dunmore et al. (2019), Lu et al. (2019), Kundu and Shen (2019) or Feng et al. (2020) as well as some more in the Chinese language as discussed in Liu et al. (2018) and Lee et al. (2018). Other less related works are Song et al. (2011), Song and Na (2012), Tsuji (2013) or Kim et al. (2020) focusing on multimodal freight transports via Trans-Siberian Railway (TSR) with a short sea leg from China, South Korea and/or Japan to Russian Far East. Another stream of literature deals with a comparison of Northern Sea Route (NSR) with Suez Channel Route (SCR) and TSR or other routes of the Belt part of BRI from/to South Korea (Moon et al., 2015; Zeng et al., 2020).

However, when comparing alternative transport modes, only a few authors go beyond just comparing the Belt and Road part of BRI by including air cargo (Seo et al., 2017; Dunmore et al., 2019; Kundu and Shen, 2019) or road haulage (Rodemann and Templar, 2014). Furthermore, while almost all studies deal with transport costs or freight rates solemnly on container shipment level, they do not take different cargo values and/or service quality needs by shippers explicitly into consideration with the notable exception of recent works by Yang et al. (2018), Bucsky (2019), Dunmore et al. (2019), Lu et al. (2019), Kundu and Sheu (2019) or Zeng et al. (2020).

In contrast, this paper takes a shipper's perspective on the modal choice to assess the competitiveness of rail freight with a wider range of alternative transport modes, where service quality attributes and cargo value are considered as a novel contribution from the previous studies. A comparative analysis with a trade-off model based on transit time and transport costs is developed to evaluate the market niche for Eurasian rail freight vis-a-vis the more established modes of transport, namely sea, air, and sea/air. In a scenario analysis, further cargo attributes influencing the modal choice are employed to further investigate for which cargo type Eurasian rail freight service is favorable. In this respect, this paper contributes to the knowledge base of Eurasian multimodal freight transport research studies by incorporating service quality and cargo value of Eurasian rail freight in the Belt and Road era.

The remainder of this paper is organised as follows. Section 2 presents a comprehensive overview of recent literature on Eurasian rail freight developments. In Section 3, service quality issues of Eurasian rail freight are highlighted to provide a basis for the comparative analysis in form of a trade-off model of transport costs and transit times compared with other modes of transport followed by a scenario analysis based on cargo type. The results of the trade-off model of transport costs and transit times and the scenario analysis based on cargo type demonstrate the market niche for Eurasian rail freight services thoroughly discussed in Section 4. Finally, Section 5 concludes with managerial implications and limitations of this study, and future research agendas are also proposed.

\section{Background and Service Characteristics}

In this section, we aim to presents an overview of the recent developments concerning Eurasian rail freight operations based on literature available in English, Russian and Chinese language 
and complemented by interviews with main players being active on this market. First, a detailed geographic overview of the two major routes and three corridors on the Belt between China and Europe will be introduced. Following a review of the Eurasian rail freight services in terms of its current routing development, types of goods transported, market players, bottlenecks in operations, and the hot-debated governmental subsidy issue. These service characteristics of Eurasian rail freight will provide a basis for us to construct the comparative and scenario analysis in this study.

\subsection{Eurasian Rail Freight Transport in the Belt and Road Era}

The Belt part of BRI connects cities in Europe with Russian Far East and China by railway lines running through East Asia, Central Asia, Southern Russia, Eastern Mediterranean, Arabian Peninsula and Europe (Lin, 2011). Given that at least some parts of this Belt follow the same track with the Ancient Silk Road, thus it is also called "New Silk Road" or "Modern Silk Road" (NDRC, 2015). The Belt includes two major rail land bridges between Europe and Asia as shown in Figure 2, namely:

- The Trans-Siberian Railway (TSR, or First Eurasian Land Bridge) served as the main land bridge between Russian Far East and Western Europe from the late 1960s until the early 1990s (Lilliopolou et al., 2005; Pieriegud, 2007). The TSR starts from the Russian Far East Pacific seaports Vladivostok and Nakhodka running west through Russian Federation to Moscow, and further reaches European countries such like Finland, Latvia and Poland through different rail routes (OSJD, 2019), at the east end, maritime links connecting the aforementioned Russian seaports with China, South Korea or Japan are also considered as a natural extension of the intermodal transport routes of this traditional Eurasian land bridge (Song et al, 2011; Song and Na, 2012; Tsuji, 2013; Moon et al., 2015; Zeng et al., 2020; Kim et al., 2020).

- The New Eurasian Land Bridge (NELB, or Second Eurasian Land Bridge) originally spans from the Pacific port of Lianyungang in China running through China, Kazakhstan, Russian Federation, Belarus to Rotterdam in the Netherlands (Islam et al., 2013; OSJD, 2019) with a variety of intermodal terminals as points of origin and destination in between.

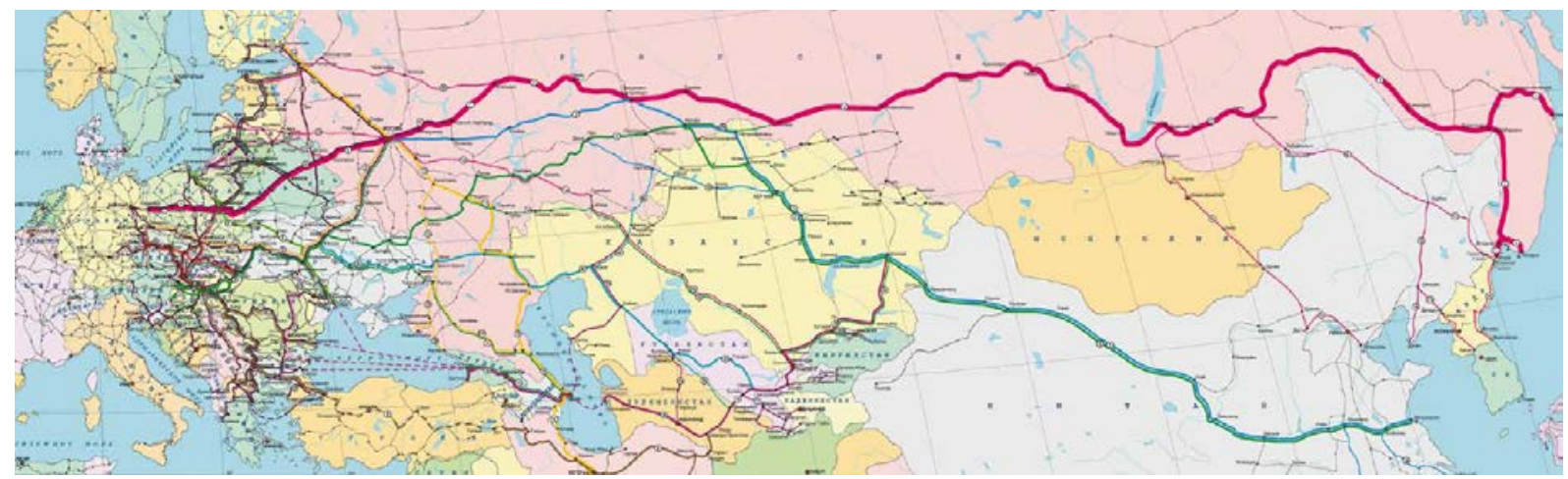

Figure 2: Route of the Trans-Siberian Railway (red) and the New Eurasian Land Bridge (green) Source:OSJD,2009

The abovementioned TSR and NELB are the current two main routes connecting Asia to Europe (Sárvári and Szeidovitz, 2016). Notably, these two major Eurasian land bridges consist of several train routings across various countries with individual branch lines that partially share 
the same main line sections as well (Rodemann and Templar, 2014). They can be described as follows:

The Northern Corridor provides three alternative branch lines connecting China and Europe via TSR (Islam et al., 2013; Galushko, 2016; OSJD, 2019), namely:

- China - TSR via Alashankou/Dostik and transit through Kazakhstan (Kazakh route)

- China - TSR via Erenhot/Zamyn-Uud and transit through Mongolia (Mongolian route)

- China - TSR via Manzhouli/Zabajkalsk (Manchurian route)

Trains on this route start in China, head via one of the three border crossings for the TSR toward the west and enter European Union at Brest/Malaszewicze, Siemianovska/Svisloch, Kuznitsa/Bruzhi or (but to much less extent) via Slovakia, Hungary, Estonia, Latvia, Lithuania, Finland and/or the Russian exclave of Kaliningrad (van Leijen, 2018b; OSJD, 2019; UTLC, 2020). However, it is noted that the classic TSR line starting in Vladivostok or Nachodka is not considered in the BRI development strategy (Sárvári and Szeidovitz, 2016).

The Central Corridor provides an alternative east-west route through Kazakhstan and Russian Federation to connect China and Europe called NELB. Trains on this route cross the Chinese Kazakh border at Alashankou/Dostik or Altynkol/Khorgos and usually run further west via railway lines south to the TSR towards the aforementioned border crossings to European Union. This route is the main target of the Belt in the BRI (Sárvári and Szeidovitz, 2016).

Meanwhile, it is worth mentioning that there is the Southern Corridor called the Trans-Caspian International Transport Route (TITR, http://titr.kz/en) upcoming which runs through Kazakhstan, the Caspian Sea, Azerbaijan and Georgia further to Turkey, Ukraine or European countries. However, this routing requires at least one ferry trip across the Caspian Sea and transcends the Caucasus towards the Black Sea or Turkey to reach Europe and these multiple border crossings, ferry trips, and current geopolitical issues in the Caucasus region make it rather unattractive (Sárvári and Szeidovitz, 2016; Bucsky, 2019).

\subsection{Service Characteristics of Eurasian Rail Freight}

In March 2011, China launched the China Railway Express (CR Express) freight service to enhance connectivity with markets in Central Asia and Europe along the Belt of BRI (Luo, 2017; Jiang et al., 2018). Originating from different parts of China, these container block trains have different routings: trains starting in the western and central part of China, namely Urumqi, Chongqing, Chengdu, Wuhan or Xi' an go via Alashankou or Altynkol to Europe, whereas trains from the east coastal and northern region such as Putian, Shengyang, Suzhou, or Zhengzhou tend to leave China via Manzhouli or Erenhot and follow the TSR to Europe (Luo, 2017; OSJD, 2019; CRCT, 2019).

Following OSJD (2019), Zhang (2019) and Bucsky (2019) most of the traffic goes along the Kazakh route. Here, the joint-stock company United Transport and Logistics Company - Eurasian Rail Alliance (UTLC) is regarded as the domain player offering services for transportation of containers by regular container block trains between China and Europe through the transit countries of Kazakhstan, Russian Federation and Belarus (UTLC, 2020).

By the end of 2018, CR Express run 65 dedicated block train lines connecting 56 Chinese cities with 49 cities in 15 European countries (China Railway Supply Chain \& Logistics, 2019). The 
main intermodal terminals on the European side were Malaszewicze, Warsaw, Duisburg or Hamburg, with some dedicated block trains also end at Budapest, Klaipeda, Lodz, London, Madrid, Muuga, Nuremberg, Pardubice, Riga, Rotterdam, Schwarzheide or Tilburg (CRCT, 2019; OSJD, 2019; Pomfret, 2019). New lanes with many more new origins in China and destinations in Europe announced from time to time in media.

However, Eurasian rail freight service operations have some idiosyncratic features concerning types of goods transported, major market players engaged in block train operations and bottlenecks and heavy subsidization of freight rates that should be taken into consideration.

\section{Types of goods transported}

Currently, most of the goods transported on these Eurasian rail freight routes between China and Europe are mainly machinery and equipment, vehicles and spare parts, household appliances, food and beverages, garment and electronic products (Wang, 2017; Bucsky, 2019), see Table 1 . The type of cargo transported by rail gradually shifted to higher value-added goods (Sárvári and Szeidovitz, 2016), whereas the types of cargo on the return trips from Europe to China are high-value machinery and equipment, vehicles and spare parts, as well as luxury goods, foods, and beverages.

Table 1 Type of goods shipped on China Railway Express

\begin{tabular}{|c|c|c|}
\hline Cargo Value & $\begin{array}{l}\text { Westbound } \\
\text { (China - Europe) }\end{array}$ & $\begin{array}{l}\text { Eastbound } \\
\text { (Europe - China) }\end{array}$ \\
\hline High-value Goods & $\begin{array}{l}\text { Machinery and equipment, } \\
\text { vehicles and spare parts, } \\
\text { electronic products }\end{array}$ & $\begin{array}{l}\text { Machinery and equipment, } \\
\text { vehicles and spare parts, } \\
\text { luxury garment and leather goods }\end{array}$ \\
\hline Low-value Goods & $\begin{array}{l}\text { Luggage, stationery, handicrafts, } \\
\text { garment, household appliance, } \\
\text { coffee beans, tea, textiles, } \\
\text { chemical products, } \\
\text { flowers and trees }\end{array}$ & $\begin{array}{l}\text { Wine, beer, milk, meat, } \\
\text { olive oil, cosmetics, timber }\end{array}$ \\
\hline
\end{tabular}

Source: Wang (2017)

\section{Major market players engaged in Eurasian container block train operations}

It is important to understand who the major players in this Eurasian container block train market are. Apart from the aforementioned CR Express and UTLC, container transports along these Eurasian rail freight corridors as shown in Section 2.1 comprise a variety of different market players due to the railway systems spanning multiple countries and operators, which forms a complex contractual network (Davydenko et al., 2012; UNECE, 2017; Jakóbowski et al., 2018; Bucsky, 2019). Table 2 shows principle market players in Eurasian rail freight container transport as identified by Pieriegud (2007), Davydenko et al. (2012), and updated based on author's desk research and interviews with main players in the Eurasian rail freight market.

Table 2: Major market players in Eurasian rail freight container transport

\begin{tabular}{|c|c|c|}
\hline Market Player & Function & Example \\
\hline Shipper & $\begin{array}{l}\text { Cargo owner, clients of for- } \\
\text { warders }\end{array}$ & $\begin{array}{l}\text { Siemens-Fujitsu, BSH, BMW, HP*, Apple*, } \\
\text { Acer*, Foxconn*, Haier*, Samsung*, Audi*, } \\
\text { Volkswagen*, Volvo*, Decathlon*, etc. }\end{array}$ \\
\hline
\end{tabular}




\begin{tabular}{|c|c|c|}
\hline Forwarder & $\begin{array}{l}\text { Organise transport } \\
\text { on behalf of shippers }\end{array}$ & $\begin{array}{l}\text { Kuehne \& Nagel, DB Schenker, DHL*, } \\
\text { GEFCO*, HAL Logistics*, Cosco Logistics*, } \\
\text { Sino Railway*, Sinotrans*, Kerry Logistics*, } \\
\text { Pantos Logistics*, DSV*, Belintertrans*, Sil- } \\
\text { virom*, Gebr. Weiss*, Panalpina*, etc. }\end{array}$ \\
\hline Container operator & $\begin{array}{l}\text { Container carrier, } \\
\text { organise dedicated block } \\
\text { trains or single container } \\
\text { transports }\end{array}$ & $\begin{array}{l}\text { InterRail Services, Russkaya Troyka, Hupac } \\
\text { International Logistics, Far Eastern } \\
\text { Transport Group (DVTG)*, Far East Land } \\
\text { Bridge (FELB)*, China Railway Express (CR } \\
\text { Express)*, Sino Railway*, Hunan Xiang Ou } \\
\text { Express Logistics*, Hao Logistics*, YuXinOu } \\
\text { Logistics*, Yiwu CF Intl. Logistics*, HLT Intl. } \\
\text { Logistics Ningbo (H\&T)*, Wuhan Asia-Eu- } \\
\text { rope Logistics (WAE)*, etc. }\end{array}$ \\
\hline National railway company & $\begin{array}{l}\text { Provision of traction, } \\
\text { infrastructure, wagons, } \\
\text { tariff policy }\end{array}$ & $\begin{array}{l}\text { Russian Railways (RZD), Belarussian Rail- } \\
\text { ways (BC), Kazakhstan Railways (KZH)*, Chi- } \\
\text { nese Railways (KZD)*, Deutsche Bahn } \\
(\mathrm{DB})^{*} \text {, Polish State Railways (PKP)*, Latvian } \\
\text { Railways (LDZ)*, Railcargo Austria* }\end{array}$ \\
\hline $\begin{array}{l}\text { Affiliated company for } \\
\text { container transport }\end{array}$ & $\begin{array}{l}\text { Organise and operate } \\
\text { intermodal transport on } \\
\text { behalf of railways }\end{array}$ & $\begin{array}{l}\text { DB Intermodal, TransContainer, KTZ Ex- } \\
\text { press*, United Transport \& Logistics Com- } \\
\text { pany (UTLC)*, CRIntermodal*, China Rail- } \\
\text { way Container Transport (CRCT)*, Trans } \\
\text { Eurasia Logistics }(T E L)^{*}, \text { YuXinOu Logistics* }\end{array}$ \\
\hline Container owners & $\begin{array}{l}\text { Own containers for own } \\
\text { transport and/or leasing; } \\
\text { shipping companies, } \\
\text { leasing companies }\end{array}$ & $\begin{array}{l}\text { Maersk, Evergreen, Seaco, China Railway } \\
\text { Express*, Far East Land Bridge (FELB)*, } \\
\text { TransContainer*, Far Eastern Transport } \\
\text { Group (DVTG)*, Pantos Logistics*, China } \\
\text { Railway Container Transport (CRCT)*, etc. }\end{array}$ \\
\hline Terminal operator & $\begin{array}{l}\text { Handling of containers } \\
\text { on behalf of container } \\
\text { transport companies } \\
\text { and container owners }\end{array}$ & $\begin{array}{l}\text { Deutsche Umschlaggesellschaft Schiene- } \\
\text { Straße (DUSS), TransContainer, Duisport*, } \\
\text { Russian Railways (RZD)*, Far Eastern } \\
\text { Transport Group (DVTG)*, CRIntermodal*, } \\
\text { China Railway Container Transport (CRCT)*, } \\
\text { PKP Cargo*, KTZ Express* }\end{array}$ \\
\hline Railway agency & $\begin{array}{l}\text { Book transport on behalf of } \\
\text { train operators }\end{array}$ & Kaztransservice, Transrail, Belintertrans* \\
\hline Customs agents & $\begin{array}{l}\text { Customs clearance on be- } \\
\text { half of forwarders }\end{array}$ & $\begin{array}{l}\text { Far Eastern Transport Group (DVTG)*, PKP } \\
\text { Cargo*, United Transport \& Logistics Com- } \\
\text { pany (UTLC)*, TransContainer*, Pantos Lo- } \\
\text { gistics*, Belintertrans* }\end{array}$ \\
\hline
\end{tabular}

Source: Pieriegud (2007), Davydenko et al., (2012), updates by the authors indicated with “*”

\section{Heavy subsidisation of freight rates}

To promote rail freight on the Belt and maintain normalised operation, operations of CR express under BRI are heavily subsidised (Bresharati et al., 2017; Qiwen and Xianliang, 2017; Jiang et al., 2018; Bucsky, 2019; Kundu and Sheu, 2019; Feng et al., 2020), varying from 1,000 to 7,000 USD per FEU (Wang, 2015; Jiang et al., 2018).

Provincial and local governments in China provide a various amount of subsidies to railway operators. The amount of subsidy will be granted based on the block train booking forecast submitted by the operators (Jiang et al., 2018) to cover the cost gap between rail and sea freight. For example, trains origins from inland cities such as Chongqing, Chengdu, Zhengzhou, and 
Wuhan received higher subsides with an average of 7,000 USD per FEU; Trains from coastal city Suzhou receive a lower subsidy of 1,000 USD per FEU (Jiang et al., 2018). Due to the imbalanced cargo volume, this subsidy even more heavily goes to covering the under-capacity running on the eastbound trip from Europe to China (Jiang et al., 2018; EUCCC, 2020).

Such subsidies may distort the freight market, since the freight rate of CR express service is often lower than its cost, and sometimes as low as sea freight rate (Chen et al., 2017; EUCCC, 2020). However, it is reported that the Chinese government plans to reduce the subsidy by 30 per cent in 2020, and abolish it entirely by 2022 (EUCCC, 2020).

\section{Bottlenecks in Eurasian rail freight operations}

Operating long-haul container block trains across multiple countries in a short time is not easy, as complex legal environment, technical limitations, physical constraints, capacity limits, and imbalanced cargo volumes post bottlenecks in Eurasian rail freight operations (Islam et al. 2013; InterRail, 2017; Besharati et al., 2017; Vinokurov et al., 2018; Jakóbowski et al., 2018). These bottlenecks are summarised in Table 3 along with improvements in the meantime.

Table 3: Bottlenecks and improvements identified in the literature

\begin{tabular}{|c|c|c|}
\hline & Bottlenecks Identified & Improvements \\
\hline \multirow[t]{2}{*}{$\begin{array}{l}\text { Complex legal } \\
\text { environment }\end{array}$} & $\begin{array}{l}\text { Differences in transport and customs law } \\
\text { lead to arbitrary transport documentation } \\
\text { and lengthy border crossing procedures } \\
\text { (Kallas, 2012, Galushko, 2016, Jakóbowski et } \\
\text { al., 2018; Zhu and Filimonov, 2018) }\end{array}$ & $\begin{array}{l}\text { The International Rail Transport Committee } \\
\text { (CIT) established a combined CIM-SMGS con- } \\
\text { signment note as a commonly accepted } \\
\text { transport document along the Belt route (Ga- } \\
\text { lushko, 2016); }\end{array}$ \\
\hline & & $\begin{array}{l}\text { The foundation of the Eurasian Customs Un- } \\
\text { ion (EACU) including the Russian Federation, } \\
\text { Belarus, and Kazakhstan in } 2010 \text { eased transit } \\
\text { through these countries and China joined the } \\
\text { TIR Carnet transit framework in } 2017 \text { which } \\
\text { allows end-to-end transit operations (UIBE } \\
\text { and IRU, 2017). }\end{array}$ \\
\hline $\begin{array}{l}\text { Technical } \\
\text { limitations }\end{array}$ & $\begin{array}{l}\text { Lack of unified standardization (e.g. railway } \\
\text { gauge) hinders the interoperability of rail- } \\
\text { way systems (Galushko, 2016, Panova et al., } \\
\text { 2018). } \\
\text { The technical infrastructure of railways en } \\
\text { route such as double track lines or electrifi- } \\
\text { cation might hinder an uninterrupted } \\
\text { transport (Liu, 2014). }\end{array}$ & $\begin{array}{l}\text { The wide-spread use of intermodal containers } \\
\text { ease these interoperability issues considera- } \\
\text { bly - but it still takes about } 2 \text { to } 21 \text { hours to } \\
\text { complete the trans-load for a container block } \\
\text { train (UTLC, 2020). }\end{array}$ \\
\hline $\begin{array}{l}\text { Physical } \\
\text { Constrains }\end{array}$ & $\begin{array}{l}\text { Extreme weather condition with minus } 40^{\circ} \\
\text { Celsius in Siberia can be a challenge for many } \\
\text { sensitive goods (Woods, 2015) }\end{array}$ & $\begin{array}{l}\text { Nowadays containers for such block trains are } \\
\text { equipped with thermal insulation and active } \\
\text { temperature control systems whenever nec- } \\
\text { essary (InterRail, 2017; UTLC, 2020). }\end{array}$ \\
\hline
\end{tabular}




\begin{tabular}{ll}
\hline Capacity & In China, a block train can carry around 55 - \\
limits & FEUs, on the TSR up to 75 FEUs, while in Eu- \\
& rope, they are usually limited to max. 44 \\
& FEUs, and also all freight trains have to give \\
priority to passenger trains (Jakóbowski et \\
al., 2018) \\
Limit on the structure gauge. This also pre- \\
vents to transport containers double- \\
stacked to add on capacity due to limited \\
clearance.
\end{tabular}

Source: Authors' own

\section{Methodology}

Employing a comparative analysis and a scenario analysis approach, the study is to examine the service quality of rail freight compared to the other current existing containerised transport solutions between China and Europe, namely sea, air, and sea/air transport modes. The sea/air concept is a multimodal transport of cargo by sea on its first leg followed by air which comes along with "half the time half the cost" (Raguraman and Chan, 1994). Moreover, the service quality of rail freight and modal choice from the shipper's perspective are highlighted in this section to provide a basis for the comparative analysis in this study. A trade-off model based on transport cost and transit time and scenario analysis based on cargo value will be constructed based on transport costs and transit time, to compare the cost and time differences of sending a containerised shipment from China to Europe by sea, air, sea/air, or rail respectively.

\subsection{Service Quality of Freight Transport}

With the purpose to examine the service quality of rail freight with other alternative transport modes, it is important to understand the 'service quality' concept and provide definitions to clarify the research scope in this study. It is commonly agreed that service quality is characterised by customer's perception of service (Shainesh and Mathur, 2000), so that it can be defined as "the difference between customer expectations of service and perceived service" (Shahin, 2006). Accordingly, when service quality is to be evaluated, the difference between the services that customers expect and the services perceived has to be examined.

To evaluate the service quality, the measurement method should be adopted to examine the difference between the services that customers expected and the services perceived. Measurement will be conducted to compare the changes in service quality, and also to identify the problems thus further improve service delivery (Shahin, 2006). 
There are an array of factors and determinants to measure service quality (Prasad and Shekhar, 2010). The most commonly used metrics for measurement of service quality is called SERVQUAL, firstly proposed by Parasuraman et al., 1988). Five dimensions - tangibles, reliability, responsiveness, assurance, and empathy are used as basic instruments for service quality measurement to examine gaps between expectations and perceptions (Parasuraman et al., 1988; Zeithaml et al., 1990). Although the SERVQUAL instruments have been widely used and proven to be valid and reliable in different service contexts, they still need to be modified and adapted to reflect specific service settings (Prasad and Shekhar, 2010).

Based on the SERVQUAL metrics, RAILQUAL has been developed as a service quality scale to measure the rail service quality passenger transport with three additional dimensions - convenience, comfort, and connection - added to the basic five SERVQUAL metrics (Prasad and Shekhar, 2010).

However, the "RAILQUAL" metrics are used for measuring the quality of rail passenger service. This study focuses on examining the quality of rail freight service and very few published literature reports the use of SERVQUAL to assess the rail freight transport service.

To understand the service quality of freight transport, variables are identified by researchers in investigating shippers' freight service decision choice between different transport modes. Matear and Gray (1993) applied principal components analysis to explore the underlying structure of the service choice decision for shippers and freight suppliers when choosing between sea and air modes of transport (see Table 4). Five principal components - carrier, route, timing, price characteristics, and control over other parties have been considered as important factors in the modal choice.

Table 4: Service attributes for service choice decision

\begin{tabular}{|l|l|}
\hline Principal Component & Service Attributes \\
\hline Carrier characteristics & $\begin{array}{l}\text { Arrival time; Fast response to problems; Handle special requirements and ur- } \\
\text { gent deliveries; Good relationship with carriers. }\end{array}$ \\
\hline Route characteristics & Proximity to origin and destination; Optimised route choice. \\
\hline Timing characteristics & High service frequency; On-time collection and delivery; Short transit time; \\
\hline Price characteristics & Low price; Value for money price; Special offer or discounts. \\
\hline Control over other parties & Transport preference of trading partner; Documentation completed carrier. \\
\hline
\end{tabular}

Source: Adapted from Matear and Gray (1993)

Among these five principal components, Matear and Gray (1993) pointed out that frequency, reliability (i.e. punctuality concerning the time of arrival) and capacity (i.e. the availability of freight space) are the most important ones. Later on, Rodemann and Templar (2014), as well as Seo et al. (2017) confirmed that transport cost, transit time, as well as transit time reliability are the major modal choice decision criteria concerning goods transports between China and Europe.

\subsection{Data Collection}

Quantitative data obtained in this study includes quotes of transport, transit time, the distance of each route for each mode on each route (see Table 5). To maintain the integrity and reliability of the data collection process, freight rates for rail, sea, air and sea/air were requested from 
major container operators or forwarders in Austria, Germany, China, and Kazakhstan. Additionally, average freight rates for sea and air were retrieved from Freightos (http://www.freightos.com) and SeaRates (http://www.searates.com) as well as cross-checked with secondary data provided by Chen et al. (2017), Jiang et al. (2018), Dunmore et al. (2019) and Drewry Shipping Consultants (https://www.drewry.co.uk/). Both freight rates and transit times presented are averages based on a sample of quotations for each transport leg.

Table 5: Data collection summary

\begin{tabular}{|c|c|c|c|}
\hline Data Collected & Data Type & Source & Collection Method \\
\hline Rail & $\begin{array}{l}\text { FEU FCL freight rate } \\
\text { for all possible routes } \\
\text { from Asia to Europe, } \\
\text { Transit time along } \\
\text { major corridors }\end{array}$ & $\begin{array}{l}\text { European and Central Asian } \\
\text { block train operators } \\
\text { Chinese and Central Asian } \\
\text { rail freight forwarders } \\
\text { Secondary data from litera- } \\
\text { ture }\end{array}$ & $\begin{array}{l}\text { Online enquiry } \\
\text { Site visits, Skype and } \\
\text { face-to-face interview } \\
\text { Secondary data collection }\end{array}$ \\
\hline Sea & $\begin{array}{l}\text { FEU FCL freight rate } \\
\text { and transit time } \\
\text { from China to Germany }\end{array}$ & $\begin{array}{l}\text { Freightos.com } \\
\text { SeaRates.com } \\
\text { World Container Index } \\
\text { (WCI) by Drewry }\end{array}$ & $\begin{array}{l}\text { Online enquiry } \\
\text { Secondary data collection }\end{array}$ \\
\hline Air & $\begin{array}{l}\text { Unit rate (per kg) } \\
\text { and transit times } \\
\text { from China to Germany }\end{array}$ & $\begin{array}{l}\text { Freightos.com } \\
\text { SeaRates.com } \\
\text { East-West Air Price Index } \\
\text { (API) by Drewry }\end{array}$ & $\begin{array}{l}\text { Online enquiry } \\
\text { Secondary data collection }\end{array}$ \\
\hline Sea/Air & $\begin{array}{l}\text { Unit rate (per kg) } \\
\text { and transit times } \\
\text { from China to Germany }\end{array}$ & $\begin{array}{l}\text { European freight forwarder } \\
\text { Sea/air freight operator }\end{array}$ & $\begin{array}{l}\text { Quotes request } \\
\text { with freight forwarder } \\
\text { Secondary data collection }\end{array}$ \\
\hline Distance & $\begin{array}{l}\text { The separate distance of } \\
\text { each transport leg and the to- } \\
\text { tal distance of each route }\end{array}$ & $\begin{array}{l}\text { SeaRates.com } \\
\text { Ecotransit.org }\end{array}$ & Online enquiry \\
\hline
\end{tabular}

Source: Authors' own

Furthermore, a set of assumptions have been made to make the different modes comparable:

- Transport routes are all terminal-terminal intermodal, excluding local cartage service at both origin and destination. Accordingly, ancillary costs (i.e. fees for customs clearance, security checks, agency, insurance, document and container handling) are not included.

- Freight rate quotations for all modes of transport are for an FEU full container load (FCL) freight-all-kinds. The cargo transported in an FEU by sea and rail is assumed max. 20 tonnes, and for air and sea/air max. 10 tonnes. Concerning transport capacity, it is assumed that max. 45 FEU can be transported per block train, max. 3 FEU per airplane and 9,000 FEU or more per vessel by sea (Woods, 2015; Bucsky, 2019; Dunmore et al., 2019).

- Transit times stated were as indicated by the freight operators or forwarders. However, delays caused by congestions at intermodal terminals, border crossing points, documentation handling processes still occur regularly (Galushka, 2016).

It is noted as all the primary data from major container operators or forwarders in Austria, Germany, China, and Kazakhstan were collected during the period from 1st June to 31st July 2017. Due to commercial consideration, confidentiality, and protection of personal data, the 
personal and company information in the data obtained were made anonymous in this study. Freight rate quotations and transit times stated may be subject to change due to the volatility of the freight rates in the marketplace. In this sense, the freight rates and transit times presented here reflect a "snapshot" of the current market situation and need to be considered in a more general context. However, the Eurasian Rail Alliance Index (http://index1520.com/) demonstrates well, that freight rates by sea and rail, in particular, did not fluctuate as much over time since 2017. The same is valid for air cargo freight rates, too, if we look on the TAC Index (https://www.tacindex.com) while abstracting from recurrent seasonality patterns.

\section{Results}

\subsection{Comparative Analysis of Transport Costs and Transit Times}

To build up a realistic and at the same challenging scenario, Shanghai in China and Hamburg in Germany were selected as the origin and destination points, as both cities have a seaport serving as a major container hub with direct connection on the China-Europe trade lane and are quite often used when it comes on freight rate benchmarking.

Table 6 summarises the transport costs and average transit times of shipping a single FCL shipment of one FEU from Shanghai to Hamburg for four modes of transport on a terminal-terminal basis for 2017 compared to figures raised by U.S. Chamber of Commerce (2006) with sea/air calculated separately based on historical freight quotations of that time available to the authors.

Table 6: Transport costs and transit times for different transport modes in 2006 and 2017

\begin{tabular}{|l|l|c|c|c|c|c|}
\hline $\begin{array}{l}\text { Transport } \\
\text { Mode }\end{array}$ & Year & $\begin{array}{l}\text { Distance } \\
\mathbf{( k m )}\end{array}$ & $\begin{array}{l}\text { Transit Time } \\
\text { (days) }\end{array}$ & $\begin{array}{l}\text { Transport Cost } \\
\text { (USD/FEU) }\end{array}$ & $\begin{array}{l}\text { Cost/Distance } \\
\text { (USD/km) }\end{array}$ & $\begin{array}{l}\text { Transport Speed } \\
\mathbf{( k m / d a y )}\end{array}$ \\
\hline Rail & 2017 & 11,249 & 16 & 6,350 & 0.56 & 703.1 \\
\hline Rail & 2006 & - & 47 & 8,450 & - & - \\
\hline Sea & 2017 & 20,053 & 32 & 2,410 & 0.12 & 626.7 \\
\hline Sea & 2006 & - & 30 & 2,740 & - & - \\
\hline Air & 2017 & 8,822 & 4 & 32,490 & 3.68 & $2,205.5$ \\
\hline Air & 2006 & - & 5 & 25,000 & - & - \\
\hline Sea/Air & 2017 & 16,008 & 19 & 16,650 & 1.04 & 842.5 \\
\hline Sea/Air & 2006 & - & 19 & 22,600 & - & - \\
\hline
\end{tabular}

Source: U.S. Chamber of Commerce (2006), own calculations.

By freight rate, the sea was and is still the cheapest option and air is very much higher than the other modes. Sea/air transport costs are around half of the air, whereas Eurasian rail freight is about $80 \%$ less costly than air and ranked next to the sea as the second cheapest option. In terms of transit time, which includes the actual time of transport plus time when a container is waiting at terminals or borders crossings for customs clearance or trans-loading gauge changes etc., air (3 to 5 days) is by far the fastest transport solution from China to Europe, and rail (14 to 16 days) or sea/air (18 to 20 days) are about half of the time than sea (usually 30 to 34 days, but could be much longer when a container is subject to transshipment en route). 
Furthermore, these different modes of transport come along with different routing, so that the distance of each mode travelled varies and cost per $\mathrm{km}$ is in line with the total transport cost of each mode. In terms of average transport speed, sea/air (about $843 \mathrm{~km} /$ day) is faster than rail (about $704 \mathrm{~km} /$ day), but due to its slower sea leg (about $627 \mathrm{~km} /$ day), the total transit time of sea/air is still higher than Eurasian rail freight.

Finally, most striking is a significant shift of transit times in the past decade from 45-50 days to 16 days on average with now only 1 or 2 days of variation due to different routing. At the same time, transport costs decreased from 8,450 USD in 2006 to nowadays 6,350 USD for an FEU from Shanghai to Hamburg. On some specific routes from inland China cities (i.e. Chongqing or Changsha) via Kazakhstan to Germany, these transport costs can be even lower with around 3,700 to 4,500 USD due to subsidies granted by provincial and local governments in China as discussed in Section 2.2.

\subsection{Scenario Analysis Based on Cargo Type}

In the previous section, it has been discovered that rail comes along with much shorter transit time than sea and much lower cost than air which qualifies it to be an alternative mode of transport to fit into the market niche of shipping high-value and time-sensitive goods. But goods transported by Eurasian rail freight cover a much wider range of cargo from high-value goods such as luxury products, machinery, equipment, vehicles and spare parts, and time-sensitive goods such as food and beverage, to general commodities such as textiles and chemical products as shown in Section 2.2.

Goods are considered to be time-sensitive when they are subject to depreciation and uncertain demand due to "inventory holding costs, perishability, rapid technological obsolesce, and uncertain demand" (Hummels, 2007; Hummels and Schaur, 2013). Furthermore, inventory holding costs include the capital cost of the goods in transit, cost of buffer stock at the destination warehouse to accommodate variation in arrival time. In addition to this, depreciation costs include spoilage of perishable goods or rapid technological obsolescence. Hence, the time of goods spend in transit will impose a combination of inventory holding and depreciation costs on consumers.

Moreover, Hummels and Schaur (2013) defined the estimated value of time per day transit time which depends mainly on the value of cargo and expressed these time costs in tariff equivalents by calculating the estimated value of one day saved in transit for each product. To reflect how much consumer's value of timely delivery for the full range of product categories being traded and shipped, it was estimated that each day of goods in transit is equivalent to a tariff of about $1 \%$ per day levied on the value of cargo for most goods employing trade and shipping data from U.S. imports of merchandise database. This estimation varies over the type of goods, as bulk products and raw materials are less time-sensitive than complex manufactures and perishable goods are subject to rapid depreciation, such as fresh fruit and vegetables (Hummels, 2007). As the daily depreciation rate of goods with high time sensitivity and high value can be as high as about $2 \%$, one day in transit translates into a tariff equivalent of $2 \%$.

When combining these findings with transit times and transport cost figures as shown in Table 4 , estimated values of time per day in transit and value to weight ratios can now be employed for scenario analysis to include time sensitivity and value of cargo transported. Then the value of time in transit (defined as a combination of inventory holding and depreciation cost) allows assessing the relations between transport costs, transit time and total logistics costs for goods 
of high versus low time sensitivity between different modes of transport. Or more strictly defined:

- Inventory holding and depreciation costs are incorporated in the form of a tariff equivalent as a proxy. In line with the estimations of Hummels and Schaur (2013), this tariff equivalent is set to $1 \%$ per day of cargo value for goods with lower time sensitivity, and $2 \%$ per day for goods with higher time sensitivity.

- Calculation of total logistics costs only include the direct transport costs and indirect inventory holding and depreciation costs during the transit expressed in this tariff equivalent.

- An average shipment is assumed to be 10 tons per FEU, so that cargo value expressed in USD per kg can be easily calculated and compared over all four modes of transport.

Results of the scenario analysis are shown in Figure 3 and can be summarised as follows: Whenever goods shipped have a low time sensitivity, and value to weight ratio is around $2.55 \mathrm{USD} / \mathrm{kg}$, rail is almost equal to sea and after around $21.78 \mathrm{USD} / \mathrm{kg}$, air gets cheaper than rail. If goods shipped have a high time sensitivity, rail is already cheaper than sea for cargo values of higher than $1.23 \mathrm{USD} / \mathrm{kg}$ and air is then cheaper when cargo value is higher than $10.89 \mathrm{USD} / \mathrm{kg}$. Hence, in both scenarios, sea is the cheapest mode of transport when cargo value is low. Then rail fits into the niche and becomes the cheaper solution for cargo values ranging from relatively low value to average and high-value goods with sea/air always coming along with higher total logistics costs.
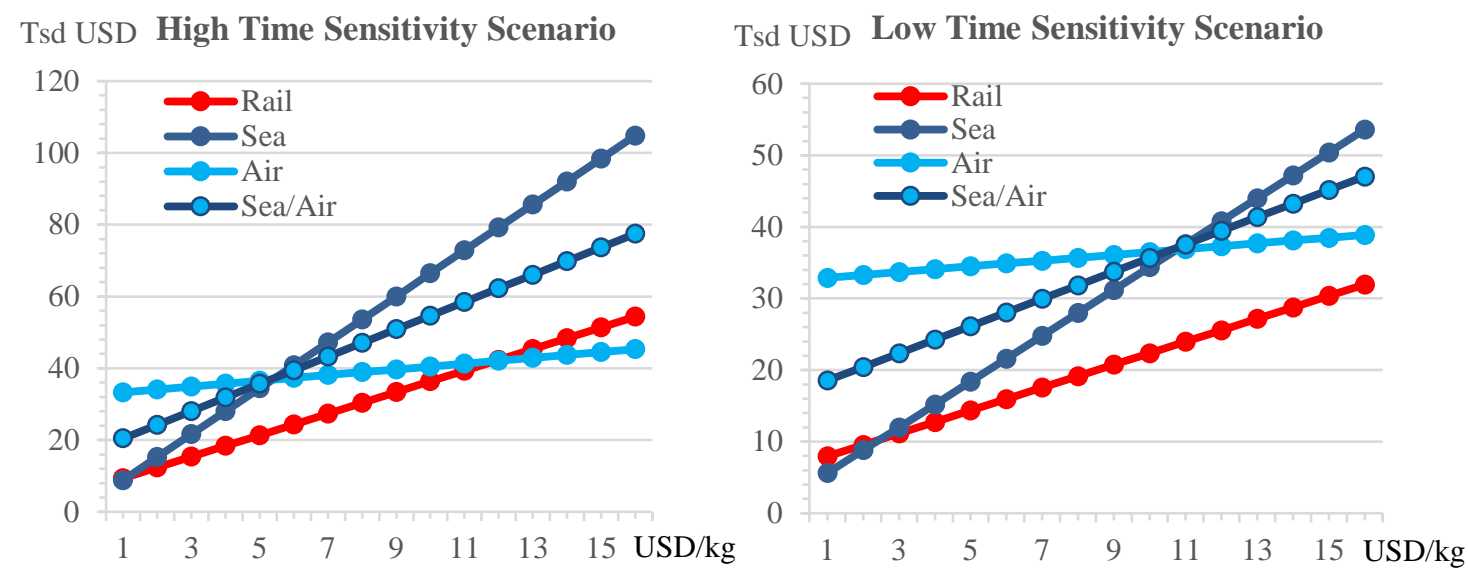

Figure 3: High time vs. low time sensitivity scenario Source: Authors’own

To put these results in a better context, EUROSTAT COMEXT Dataset DS-043327 can be employed to get further insights about shipments running between China (including Hong Kong and Macao) and European Union (EU), classified according to Harmonized System (HS). In 2018, a wide range of goods was exported from China to EU with a value to weight ratio of around $0.41 \mathrm{USD} / \mathrm{kg}$ (HS Chapter 25-27: mineral products) to $338.90 \mathrm{USD} / \mathrm{kg}$ (HS Chapter 9799: works of art, collector pieces and antiques) and imports to EU average $7.26 \mathrm{USD} / \mathrm{kg}$ (see Table 7). Goods exported from EU to China came along with a value to weight ratio of 5.65 USD $/ \mathrm{kg}$ on average and range from $0.34 \mathrm{USD} / \mathrm{kg}$ (HS Chapter 44-46: wood and articles of wood) to 4,412.56 USD/kg (HS Chapter 71: jewelry, etc.) in 2018. 
Table 7: Average value to weight ratios in USD/kg by mode of transport in 2018

\begin{tabular}{|l|c|c|c|c|}
\hline & Total & Sea & Rail & Air \\
\hline Import (CIF) China to EU & 7.26 & 4.95 & 11.04 & 80.83 \\
\hline Export (FOB) EU to China & 5.65 & 2.04 & 13.01 & 117.43 \\
\hline Maximum Carrier Liability & - & 3.54 & 24.07 & 31.15 \\
\hline
\end{tabular}

Source: EUROSTAT COMEXT Dataset DS-043327, own calculations

Furthermore, it is important to note that according to applicable transport law and/or general terms of conditions, carriers on all transport modes have certain liability limits for loss or damage of goods being transported. For example, air carrier liability is limited to about max. 31.15 USD/kg (22 SDR/kg following to Montreal Convention of 1999 or IATA Resolution 660a effective 28 December 2019), in rail freight it is max. $24.07 \mathrm{USD} / \mathrm{kg}$ (17 SDR/kg according to CIM of 1999 and SMGS of 2015 with no limitation other than the value of cargo) and in sea freight usually max. $3.54 \mathrm{USD} / \mathrm{kg}$ (2.5 SDR/kg in Hague-Visby Rules of 1968, see e.g. https://www.ivt-int.org/en/basics/). This, in turn, gives a strong indication, which goods are prone to be transported by sea, air, and rail: low-value goods by sea, high-value goods by air and rail is (again) in between and value of cargo within the liability limits of the respective carriers on average (see Table 7).

Focusing on rail mode of transport only, we get a value to weight ratio of shipments between 0.13 USD/kg (HS Chapter 44-46: wood and articles thereof) and 292.82 USD $/ \mathrm{kg}$ (HS Chapter 97-99: works of art, collector pieces and antiques) with an average of 11.04 USD/kg in 2018. However, 42.79 \% of all westbound rail traffic by weight from China to EU in 2018 is dominated by machinery and equipment with a value to weight ratio of $14.66 \mathrm{USD} / \mathrm{kg}$ (see Table 8). Eastbound traffic to China consists mainly of vehicles and spare parts, machinery and equipment followed by some low value, but heavyweight products (see Table 8).

Table 8: Top 5 of goods transported by rail between China and EU in 2018

\begin{tabular}{|l|c|c|l|c|c|}
\hline Imports (FOB) China to EU & $\%$ & USD/kg & Exports (CIF) EU to China & $\%$ & USD/kg \\
\hline $\begin{array}{l}\text { HS Chapter 84-85: } \\
\text { Machinery and equipment }\end{array}$ & 42.79 & 14.66 & $\begin{array}{l}\text { HS Chapter 86-89: } \\
\text { Vehicles and spare parts }\end{array}$ & 27.88 & 21.47 \\
\hline $\begin{array}{l}\text { HS Chapter 72-83: } \\
\text { Base metals and articles }\end{array}$ & 13.79 & 3.19 & $\begin{array}{l}\text { HS Chapter 84-85: } \\
\text { Machinery and equipment }\end{array}$ & 13.83 & 21.08 \\
\hline $\begin{array}{l}\text { HS Chapter 94-96: } \\
\text { Miscellaneous manufactures }\end{array}$ & 7.57 & 7.08 & $\begin{array}{l}\text { HS Chapter 44-46: } \\
\text { Wood and articles thereof }\end{array}$ & 13.67 & 0.13 \\
\hline $\begin{array}{l}\text { HS Chapter 50-63: } \\
\text { Textiles and textiles articles }\end{array}$ & 6.72 & 9.62 & $\begin{array}{l}\text { HS Chapter 72-83: } \\
\text { Base metals and articles }\end{array}$ & 12.92 & 4.00 \\
\hline $\begin{array}{l}\text { HS Chapter 86-89: } \\
\text { Vehicles and spare parts }\end{array}$ & 5.80 & 8.62 & $\begin{array}{l}\text { HS Chapter 47-49: } \\
\text { Pulp of wood and articles }\end{array}$ & 11.19 & 0.78 \\
\hline
\end{tabular}

Source: EUROSTAT COMEXT Dataset DS-043327, own calculations

Cargo value is not the only way to explain the market niche of Eurasian rail freight as the modal choice depends on time sensitivity, too. Based on the above findings, the preferred modal choice from a shipper's point of view can be split in 2x2 scenarios (see Figure 4) as follows: 


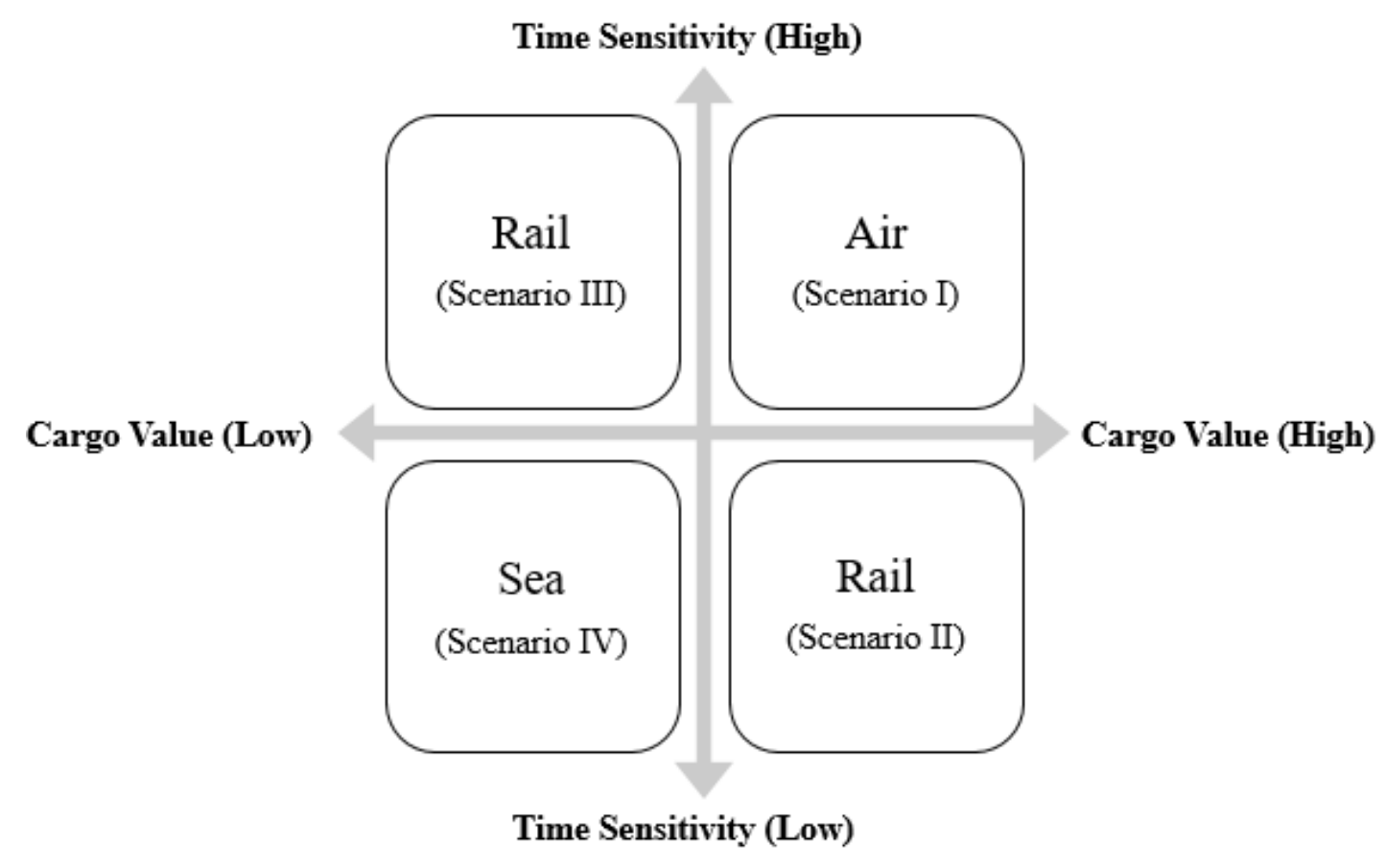

Figure 4: Preferred modal choice in different scenarios Source: Authors'own

Scenario I: High-value cargo with high time sensitivity: Whenever cargo value is above 12 USD/kg (i.e. 120,000 USD per FEU), it can be generally considered as high-valued (U.S. Chamber of Commerce, 2006). This is especially true for equipment, spare parts, and electronic products among the goods of HS Chapter 84-89, which may require frequent weekly replenishment. In this scenario, air with the shortest transit time of less than one week and most of the time the lowest total logistics costs is the most favourable solution. However, whenever special space and weight limitations or restrictions on the transport of dangerous goods and lithium batteries occur for air, rail with less restriction on cargo type and much larger capacity available might be an alternative solution at least in some cases.

Scenario II: High-value cargo with low time sensitivity: High-value cargo with low time sensitivity can be luxury garments and leather goods. In this scenario, rail with about two weeks transit time can cover a wide range of goods from $2.46 \mathrm{USD} / \mathrm{kg}$ to $21.48 \mathrm{USD} / \mathrm{kg}$ with the lowest total logistics costs in comparison to all other modes of transport.

Scenario III: Low-value cargo with high time sensitivity: When the average cargo value is around 6 USD/kg (i.e. 60,000 USD per FEU) or less, this can be considered as low-value cargo. In this scenario, for goods with short lead-time demand (e.g. high-fashion apparel, electronic products), rail continues to be the favourable option with half of the transit time than sea and much lower transport cost and larger capacity than air. Rail is able to provide the cheapest total logistics cost for a range from $1.23 \mathrm{USD} / \mathrm{kg}$ to $10.89 \mathrm{USD} / \mathrm{kg}$.

Scenario IV: Low-value cargo with low time sensitivity: For the majority share of transport goods with low-value of less than $2.46 \mathrm{USD} / \mathrm{kg}$, sea with by the far largest shipping capacity available is the cheapest solution closely followed by rail. 


\section{Conclusions}

This study examined the service quality of Eurasian rail freight based on transit times and transport costs, and scenario analysis with a special focus on cargo type and associated total logistics costs have been used to identify its market niche from a shipper's point of view. Taking the transport of an FEU from Shanghai to Hamburg as an example, we found that present Eurasian rail freight service fits into the sweet spot between sea and air. Eurasian rail freight is about $80 \%$ cheaper than air with only half of the transit time of conventional sea. Our scenario analysis further suggests that when shipping time-sensitive goods with cargo values ranging from $1.23 \mathrm{USD} / \mathrm{kg}$ to $10.78 \mathrm{USD} / \mathrm{kg}$, rail is cheaper than all other modes of transport and much faster than sea - the same is valid for goods with lower time sensitivity ranging from 2.46 $\mathrm{USD} / \mathrm{kg}$ to $21.78 \mathrm{USD} / \mathrm{kg}$.

\subsection{Managerial Implications}

Moreover, some practical recommendations on the way forward for Eurasian rail freight service development in the Belt and Road era should be noted. On a strategic level, high-level collaborations among the government of countries and railway stakeholders along the Belt of BRI are required to foster favourable legal and technical agreements to facilitating Eurasian rail freight operations. On an operational level, keep rail freight rates low to maintain competitiveness, optimise routing to lower transit times, target market to seize profit, improve public awareness to gain business are recommended for Eurasian rail freight operators to keep developing in this new Belt and Road era.

BRI is considered as a major enabler to the rapid development of Eurasian rail freight within the last decade and it can be regarded favourable in several ways:

\section{Faster than sea and cheaper than air}

In Section 4.1, a general comparison based on the costs and transit times among rail, sea, air and sea/air was conducted, which pointed out that Eurasian rail freight is about $80 \%$ cheaper than air with only half of the transit time of sea. Besides, a historical shift of its positioning in the market has also been captured - its transit time has significantly shortened from one month (or more) to only two weeks or even less. The driving force behind this significant improvement of its service in recent years can be traced back to two main factors. On one hand, BRI focuses on the Central Corridor rather than the traditional Northern Corridor, which helps to boost the domestic economy in the rural western part of China, as well as avoids dealing with Russian monopoly on the TSR. Therefore, new railway infrastructure projects and dedicated container block train services launched under BRI have greatly revived Eurasian rail freight. On the other hand, changes to global trading patterns and increasing demand for the speed to market also drive the development of intermodal logistics solutions both within Europe and along the New Silk Road (Davies, 2017).

\section{Alternative to air for time-sensitive goods}

Certainly, a pure transport cost comparison is not sufficient, as other costs occur during the transport process like inventory-holding and depreciation costs are worth taking into consideration. Therefore, in Section 4.2, they have been incorporated to compare the total logistics costs of rail, sea, air as well as sea/air where rail stands out as the most favourable transport solution when it comes on time-sensitive goods with a cargo value ranging from $1.23 \mathrm{USD} / \mathrm{kg}$ to 10.89 USD $/ \mathrm{kg}$. In the past, air used to be the only option when shipping high-value, time-sensitive goods. But as transit time shortened and transport service got more reliable, rail becomes a 
perfect alternative for time-sensitive goods, especially for those with average cargo value not necessarily worth to be transported by air. Besides, rail freight with higher capacity than air can accommodate almost all kinds of containerised cargo, which again demonstrates higher service availability.

Alternative to sea for low-value goods

Again, our scenario analysis found that when shipping goods with low time sensitivity, rail would be the cheapest option for cargo ranging from $2.46 \mathrm{USD} / \mathrm{kg}$ to $21.78 \mathrm{USD} / \mathrm{kg}$. Sea used to be the best option for low-value goods. However, present short-term flexibility tactics executed by liner shipping companies like slow steaming and re-routing of the vessel as well as blanking of sailings results in longer and less reliable transit times (Munim and Schramm, 2016; Finnsgård et al., 2018) and this cannot fulfil the requirement for today’s agile supply chains. In this case, rail with a speed advantage over sea can also cover a wide range of goods from low to high value. Instead of upgrading from sea to air (or sea/air), rail gives the customer a window of opportunity to meet deadlines without bearing the full expense of air.

Since the global economy continues to slow down, the world searches for new engines to drive trade growth, the BRI offers "a major development framework and opportunity for connectivity, international trade and economic development” (Davies, 2017). The momentum of Eurasian rail freight has already been witness to enhance connectivity and trade growth between China and Europe. Implications of this on supply chains can be summarised as follows:

\section{Not competition, but another option}

Our calculations in Section 4.1 demonstrate that Eurasian rail freight service is an emerging competitive solution - faster than sea and significantly cheaper than air. However, rather than being seen as a threat, it provides a potential alternative for companies that no longer like to consider air (or sea/air) as the only option when shipping high-value and/or more time-sensitive goods. This offers a cost-efficient option to tailor freight lead time relevant to production.

\section{The value of short transit time}

Matear and Gray (1993) suggested that when shipper and freight forwarders deciding on freight service choice, transit time is frequently considered as more important than a low freight rate. As shown in Section 4.2, a substantial amount of inventory holding and depreciation costs will add up to the total logistics costs during transport if the transit time of a shipment is too long. This is especially critical for perishable or time-sensitive goods with frequent changes in consumer preferences (U.S. Chamber of Commerce, 2006). Eurasian rail freight with shorter transit time than conventional sea and higher reliability can help shippers to reduce total logistics costs and gain more flexibility on cash flow and liquidity.

\section{Bring agility to supply chains}

Shorter and more reliable transit times give Eurasian rail freight advantage of higher accountability. On one hand, this will allow companies to have more control over their logistics operation and production forecasting; on the other hand, it will encourage companies to conduct "just-in-time" business practices with timely delivery to reduce production costs by minimising inventory (U.S. Chamber of Commerce, 2006). Besides, with more frequent scheduled container block trains and adding more terminals of origin and destination, the Eurasian rail freight service can offer a variety of end-to-end routing options, which again gives shippers more flexibility than sea and air. Moreover, high reliability of service delivery and flexibility of service 
availability will bring agility to the company's supply chains, which potentially offer companies a chance to tailor-made their supply chains based on different product categories.

\subsection{Research Limitations and Future Research Directions}

Reflecting research process and findings, some limitations have to be remarked. First, this paper intends to examine the service quality of Eurasian rail freight and compares it with other modes of transport. By doing this, firstly it focused on two quantifiable attributes - transport costs and transit time. Of course, other important attributes contribute to service quality as well, such as transit time reliability, service availability, environmental impact, etc., which are much harder to quantify.

Secondly, given that the Eurasian rail freight market is still in its infancy state (Sárvári and Szeidovitz, 2016), rail freight quotes collected by the authors may not fully reflect long-term competitive freight rates that companies get in the markets, as freight quotes obtained e.g. from freight forwarders might be already being bundled with other value-adding services on top of bare costs of rail transport. Moreover, Eurasian rail freight operations under BRI are still heavily subsidised as discussed in Section 2.2, which may to some degree hide real costs of transport service provision. Besides this, the costs of local cartage service at both origin and destination as well as other ancillary costs were not included in our calculations.

In sum, this study does not intend to provide a price list for individual business decisions, however, it does offer guidance for assessing transport options available for shippers. Last but not least, much larger data samples, specific cost models and detailed market inquiry are required to get the full picture.

Accordingly, further research should investigate traffic volume on the different rail routes as shown in Section 2.1 to capture the Eurasian rail freight market landscape, thus identifying market demand for rail and providing recommendations for further route optimisation. However, present scarcity and opaqueness of statistics available to the public make it almost impossible to determine the impact of BRI to the full extent (Bucsky, 2019).

Another direction would be to collect more detailed data of freight costs and transit time which enables to compare total logistics cost of shipping goods from specific origins to destinations by rail, sea, air, and sea/air respectively.

Finally, some other key attributes of service quality briefly outlined in Section 3.1 such as transit time reliability or service availability not explicitly included here in our analysis could be assessed. However, to raise representative data in this respect needs a tight collaboration by major market players engaged in Eurasian container block train operations alike the Clean Cargo Working Group (https://www.clean-cargo.org/) in liner shipping as yet, no public data like detailed train schedules or geolocations of block trains is available at all. 


\section{Reference}

Arduino, A. (2016), China's One Belt One Road: Has the European Union Missed the Train?, S. Rajaratnam School of International Studies (RSIS) Policy Report, available at: https://www.rsis.edu.sg/wp-content/uploads/2016/03/PR160307_China-One-Belt-OneRoad.pdf. (accessed 13 February 2020).

Besharati, B., Gansakh, G., Liu, F., Zhang, X., Xu, M. (2017), “The ways to maintain sustainable China-Europe block train operation”, Business and Management Studies 3(3), pp.25-33.

Brinza, A. (2017), "China’s Continent-Spanning Trains Are Running Half-Empty", Foreign Policy, [online], available at: https://foreignpolicy.com/2017/06/05/chinas-continent-spanningtrains-are-running-half-empty-one-belt-one-road-bri/ (accessed 13 February 2020).

Bucsky, P. (2019), "The iron Silk Road: how important is it?", Development and Policy, [online] https://doi.org/10.1080/23792949.2019.1672571.

Chang, H.H. and Huang, W.C. (2006), "Application of a quantification SWOT analytical method", Mathematical and Computer Modelling 43(1), pp.158-169.

Chen, X., Zhu, X., Zhou, Q., Wong, Y.D. (2017), "Game-Theoretic Comparison Approach for Intercontinental Container Transportation", Journal of Advanced Transportation, [online], https://doi.org/10.1155/2017/3128372.

China Railway Supply Chain \& Logistics. (2019), “2018 年中欧班列最新数据落地! 各省地区数 据公布” [The latest data of the China-Europe Railway Trains in 2018! Data release by Province], available at: https://www.amiue.com/p/6689/ (accessed 13 February 2020).

CRCT (2019), 中欧班列简介 [About China Europe Train], China Railway Container Transport, available at: http://www.crct.com/index.php?m=content\&c=index\&a=lists\&catid=22 (accessed 13 February 2020).

Davies, M. (2017), "Modish response to new 'normal"', Logistics Manager No.4/2006, pp.34-37.

Davydenko, I., Landa, M.I., Martens, R., Nesterova, N., Wark, T. (2012), Potential for Eurasia land bridge corridors \& logistics developments along the corridors, Research Paper 6th Framework Programme, European Commission, Brussels.

DB Schenker.(2019), "DB Schenker Greater China launches two CR Express new trains" [online], available at: https://www.dbschenker.com/cn-en/about/press/corporate-news/db-schenkergreater-china-launches-two-cr-express-new-trains-607892 (accessed 13 December 2019.

Dunmore, D., Preti, A., Routaboul, C. (2019), "The "Belt and Road Initiative": impacts on TEN-T and on the European transport system", Journal of Shipping and Trade 4(1), 10.

EUCCC (2020), The road less travelled, European Union Chamber of Commerce in China (EUCCC), Beijing, available at: https://www.europeanchamber.com.cn/en/publicationsbelt-and-road-initiative (accessed 13 February 2020).

Feng, F., Zhang, T., Liu, C., Fan, L. (2020), "China Railway Express Subsidy Model Based on Game Theory under "the Belt and Road" Initiative", Sustainability 12(5), 2083.

Finnsgård, C., Kalantari, J., Raza, Z. Roso, V., Woxenius, J. (2018), "Swedish shippers’ strategies for coping with slow-steaming in deep sea container shipping", Journal of Shipping and Trade 3(1), pp.1-24. 
Galushko, D. (2016) Study on Corridors, Intergovernmental Organisation for International Carriage by Rail (OTIF), Berne, available at: https://cutt.ly/1eFwy2R, (accessed 13 February 2020).

Hummels, D. (2007), "Transportation Costs and International Trade in the Second Era of Globalization", Journal of Economic Perspectives 21(3), pp.131-154.

Hummels, D., Schaur, G. (2013), "Time as a Trade Barrier", American Economic Review 103(7), pp.2935-2959.

InterRail (2017) ИнтерРейл Сервис - железнодорожные и мультимодальные грузоперевозки [InterRail Service - rail and multimodal trucking], [online] available at: http://www.interrail.ru/en/news/company-news/1032/, (accessed 05 June 2017).

Islam, D.M.Z., Zunder, T.H., Jackson, R., Nesterova, N., Burgess, A. (2013), "The potential of alternative rail freight transport corridors between Central Europe and China", Transport Problems 8(4), pp.45-57.

Jakóbowksi, J., Poplawski, K., Kaczmarski, M. (2018), The Silk Railroad, OSW Studies No.72, Warshaw.

Jiang, Y., Sheu, J.B., Peng, Z., Yu, B. (2018), "Hinterland patterns of China Railway (CR) express in China under the Belt and Road Initiative: A preliminary analysis", Transportation Research Part E 119, pp.189-201.

Jiang, Y., Qiao, G., Lu, J. (2019), "Impacts of the New International Land-Sea Trade Corridor on the Freight Transport Structure in China, Central Asia, the ASEAN countries and the EU", Research in Transportation Business \& Management, https://doi.org/10.1016/j.rtbm.2019.100419

Kim, G. S., Lee, S. W., Seo, Y. J., Kim, A. R. (2020), "Multimodal transportation via TSR for effective Northern logistics", Maritime Business Review, https://doi.org/10.1108/MABR07-2019-0029

Knowler, G. (2017), "Rising China-Europe backhaul demand spurs new services", Journal of Commerce [online], available at: https://www.joc.com/rail-intermodal/forwarder-reportsstrong-demand-europe-china-rail-services_20170509.html (accessed 20 February 2020).

Kuester, F. (2017), "The New Silk Road - The Vision of an interconnected Eurasia Combined Transport", Combined Transport Magazine [online], available at: http://combinedtransport.eu/the-new-silk-road-obor. (accessed 13 February 2020)

Kundu, T., Sheu, J.B. (2019), "Analyzing the effect of government subsidy on shippers' mode switching behavior in the Belt and Road strategic context", Transportation Research Part E, 129, pp. 175-202.

Van der Leer, Y., Yau, J. (2016), China's New Silk Route: The Long and Winding Road, PwC's Growth Market Centre [online], available at: https://www.pwc.com/gx/en/growth-marketscenter/assets/pdf/china-new-silk-route.pdf (accessed 13 February 2020).

Lee, P.T.W., Hu, Z.H., Lee, S.J., Choi, K.S., Shin, S.H. (2018), "Research trends and agenda on the Belt and Road (B\&R) initiative with a focus on maritime transport", Maritime Policy \& Management 45(3), pp.282-300.

Lin, C. (2011), "China's New Silk Road to the Mediterranean: The Eurasian Land Bridge and Return of Admiral Zheng He", ISPSW Strategy Series: Focus on Defense and International Security 49(165), pp.1-23. 
Liu, W., Song, Z., Liu, Z., Yelken, W., Song, T. Niu, F., Han, M. (2018), "一带一路"建设研究进 展" [Progress in research on the Belt and Road Initiative], Acta Geographica Sinica 73(4), pp.620-636.

Liliopoulou, A., Roe, M., Pasukeviciute, I. (2005), "Trans Siberian Railway: from inception to transition", European Transport 29, pp.46-56.

Lu, M., Chen, Y., Morphet, R., Lu, Y., Li, E. (2019), "The spatial competition between containerised rail and sea transport in Eurasia", Palgrave Communications 5(1), pp.1-11.

Matear, S., Gray, R. (1993), "Factors Influencing Freight Service Choice for Shippers and Freight Suppliers", International Journal of Physical Distribution \& Logistics Management 23(2), pp.25-35.

Modor Intelligence (2019), China-Europe Rail Freight Transport Market - Growth, Trends, and Forecast (2019-2024), [online], available at https://www.mordorintelligence.com/industryreports/china-europe-rail-freight-transport-market (accessed 13 February 2020).

MOFCOM (2020), 2019 年经哈萨克斯坦开行中欧班列大幅增长 [Central and European trains run significantly in Kazakhstan in 2019] Ministry of Commerce of China, available at: http://www.mofcom.gov.cn/article/i/jyjl/e/202001/20200102929219.shtml (accessed 13 February 2020).

Moon, D.S., Kim, D.J., Lee, E.K. (2015), "A Study of Competitiveness of Sea Transport By Comparing International Transport Routes between Korea and EU", Asian Jounral of Shipping and Logistics 31(1), pp.1-20.

Munim, Z.H., Schramm, H.-J. (2017), "Forecasting container shipping freight rates for the Far East - Northern Europe trade lane", Maritime Economics and Logistics 19(1), pp.106-125.

NDRC (2015) Vision and Actions on Jointly Building Silk Road Economic Belt and 21st-century Maritime Silk Road, National Development and Reform Commission (NDRC), available at: http://en.ndrc.gov.cn/newsrelease/201503/t20150330_669367.html (accessed 05 June 2017).

OSJD (2009) "Map of OSJD Railway Transport Corridors (as of December 2009)", available at: http://en.osjd.org/dbmm/download?vp=68\&load=y\&col_id=121\&id=258 (accessed 28 March 2020).

OSJD (2019) "List of Container and Contrailer Trains on the Railways of the OSJD Member Countries (as of 11.10.2019)", OSJD Bulletin No. 5-6/2019, pp. 91-111.

Otsuka, S. (2001), "Central Asia's rail network and the Eurasian land bridge", Japan Railway \& Transport Review 28(9), pp.42-49.

Panova, Y., Hilletofth, P., Krasinskaya, J. (2018), "Mitigating the break-of-gauge problem in international transportation corridors", World Review of Intermodal Transportation Research 7(7), pp.124-146.

Parasuraman, A., Zeithaml, V.A., Berry, L.L. (1988), "Servqual: A multiple-item scale for measuring consumer perc", Journal of Retailing 64(1), pp.12-40.

Pieriegud, J. (2007), "Container Transport on the CIS Railway Network", Railway Market - CEE Review No.2/2007, pp.8-15.

Pomfret, R. (2019), "The Eurasian Landbridge and China's Belt and Road Initiative: Demand, supply of services and public policy", The World Economy 42(6), pp. 1642-1653. 
Prasad, M.D., Shekhar, B.R. (2010), "Development of Railqual: A Service Quality Scale for Measuring Indian Railway Passenger", Management Science and Engineering 4(3), pp.8794.

Van der Putten, F.P., Meijnders, M. (2015), "China, Europe and the Maritime Silk Road", Clingendael Netherlands Institute of International Relations, Den Haag.

Qiwen, D.U., Xianliang, S.H.I. (2017), "A Study on the Government Subsidies for CR Express Based on Dynamic Games of Incomplete Information", Periodica Polytechnica Transportation Engineering 45(3), pp.162-167.

Raguraman, K., Chan, C. (1994), "The development of sea/air intermodal transportation", Logistics and Transportation Review 30(4), pp.379-396.

Rastogi, C., Arvis, J.-F. (2014), "The Eurasian Connection", World Bank, Washington DC.

Regmi, M.B., Hanaokab, S. (2012), "Assessment of intermodal transport corridors: Cases from North-East and Central Asia", Research in Transportation Business \& Management 5(12), pp.27-37.

Rodemann, H., Templar, S. (2014), "The enablers and inhibitors of intermodal rail freight between Asia and Europe", Journal of Rail Transport Planning and Management 4(3), pp.70-86.

Rodrigue, J.-P. (2017), "The Geography of Transport Systems". Routledge, New York.

Sárvári, B., Szeidovitz, A. (2016), "The Political Economics of the New Silk Road", Baltic Journal of European Studies 6(1), 3-27.

Seo Y.J., Chen, F., Roh, S.Y. (2017), "Multimodal Transportation: The Case of Laptop from Chongqing in China to Rotterdam in Europe", Asian Journal of Shipping and Logistics 33(3), pp.155-165.

Shahin, A. (2006), "SERVQUAL and model of service quality gaps: A framework for determining and prioritizing critical factors in delivering quality services", In: Partha Sarathy V., (ed.). Service quality - An introduction. ICFAI University Press, Andhra Pradesh, pp.117-131.

Shainesh, G., Mathur, M. (2000), "Service Quality Measurement: The Case of Railway Freight Services", Vikalpa 25(3), pp.15-22.

Song, J.Y., Song, M.S., Na, H.S. (2011), "A Study of Efficiency and Prioritize of Eurasian Logistics Network", International Journal of Economics and Management Engineering 5(4), pp.350355.

Song, J.Y., Na, H.S. (2012), "A Study on the Intercontinental Transportation Competitiveness Enhancement Plan between Northeast Asia and Europe Using the Trans-Siberian Railway", International Journal of Engineering and Technology 4(2), pp.208-212.

Song, L. (2015), "Vision and Actions on Jointly Building Silk Road Economic Belt and 21st-Century Maritime Silk Road", Belt and Road Portal, available at: https://eng.yidaiyilu.gov.cn/qwyw/qwfb/1084.htm (accessed 13 February 2020),

Tian, J. (2016), "One Belt and One Road: Connecting China and the world", McKinsey \& Company, available at: http://www.mckinsey.com/industries/capital-projects-andinfrastructure/our-insights/one-belt-and-one-road-connecting-china-and-the-world (accessed 20 March, 2016),

Tsuji, H. (2013), "Competitive Advantages and Disadvantages of Trans-Siberian Railway Route", International Journal of Railway 6(4), pp.139-147. 
UIBE and IRU (2017), "TIR and the facilitation of unimpeded trade for China", International Road Transport Union (IRU), Geneva.

UIC and Roland Berger (2017), "Study Euroasian rail corridors - What opportunities for freight stakeholders?", International Union of Railways (UIC), Paris, available at https://uic.org/com/IMG/pdf/corridors_exe_sum2017_web.pdf (accessed 05 June 2017).

UNECE (2012), "Euro-Asian Transport Links Phase II Expert Group Report", Final Report WP.5/2012/3. United Nations Economic Commission for Europe (UNECE), Geneva.

UNECE (2017), "Draft Euro-Asian Transport Links Phase III Expert Group Report", Informal Document WP.5/2017/6. United Nations Economic Commission for Europe, Geneva.

U.S. Chamber of Commerce (2006), "Land Transport Options between Europe and Asia: Commercial Feasibility Study", U.S. Chamber of Commerce, Washington.

UTLC (2020), "UTLC Eurasian Rail Alliance \#ENJOYTHERAIL, JSC UTLC ERA", Moscow, available at: https://www.utlc.com/en/routes/ (accessed 13 February 2020).

van Leijen, M. (2018a), "The Poland-Belarus border crossing: what are the alternatives?", available at: https://www.railfreight.com/beltandroad/2018/10/16/the-poland-belarusborder-crossing-what-are-the-alternatives/?gdpr=accept (accessed 13 February 2020).

van Leijen, M. (2018b), "Only fully loaded trains to depart from China", available at: https://www.railfreight.com/beltandroad/2018/10/23/only-fully-loaded-trains-to-departfrom-china/ (accessed 13 February 2020).

Vinokurov, E., Lobyrev, V., Tikhomirov, A., Tsukarev, T. (2018), Silk Road Transport Corridors, MPRA Paper No. 86184, Munich.

Wang, Y. (2015), "Status, problems and suggestions on development of Sino-Europe block trains", China Transportation Review 37(S1), pp.70-75.

Wang, D. (2017), "2016 年大陆桥运输指标与中欧班列相关数据分析及 2017 年中欧、中亚班 列发展预测" [2016 Continental Bridge Transportation Index and China Railway Express Data Analysis and 2017 China Railway Express Development Forecast], New Silk Road Horizon No.3/2017, pp.23-36.

Waters, W. (2017), "Sea freight constraints create Europe-Asia air freight boom", Lloyd's Loading List [online], available at: http://www.lloydsloadinglist.com/freight-directory/news/Seafreight-constraints-create-Europe-Asia-air-freight-boom/68890.htm\#.WXB4RtOGOHo (accessed 20 February 2020),

Wen, X., Ma, H. L., Choi, T. M., Sheu, J. B. (2019), "Impacts of the Belt and Road Initiative on the China-Europe trading route selections", Transportation Research Part E: Logistics and Transportation Review, 122, pp.581-604.

Wiegmans, B., Janic, M. (2019), "Analysis, modeling, and assessing performances of supply chains served by long-distance freight transport corridors", International Journal of Sustainable Transportation 13(4), pp.278-293.

Woods, R. (2015), "Intermodal motion", Air Cargo World No.10/2015, pp.36-38.

Yang, D., Pan, K., Wang, S. (2018a), "On service network improvement for shipping lines under the one belt one road initiative of China", Transportation Research Part E: Logistics and Transportation Review, 117, pp.82-95. 
Yang, D., Jiang, L., Ng, A.K. (2018b), "One Belt one Road, but several routes: A case study of new emerging trade corridors connecting the Far East to Europe", Transportation Research Part A: Policy and Practice 117, pp.190-204.

Zeithaml, V.A., Parasuraman, A., Berry, L.L. (1990), Delivering quality service: Balancing customer perceptions and expectations, Simon and Schuster, New York.

Zeng, Q., Lu, T., Lin, K. C., Yuen, K. F., Li, K. X. (2020), "The competitiveness of Arctic shipping over Suez Canal and China-Europe railway". Transport Policy, 86, pp.34-43.

Zhang, G. (2019), "The Iron Belt: China Railway Express", available at: https://marketinsights.upply.com/en/the-iron-belt-china-railway-express (accessed 13 February 2020).

Zhu, Y., Filimonov, V. (2018), “Comparative Study of International Carriage of Goods by Railway between CIM and SMGS”, Frontiers of Law in China 13(1), pp.115-136. 


\section{Appendix}

Comparative Research on Eurasian Rail Freight

\begin{tabular}{|c|c|c|c|c|}
\hline Author & $\begin{array}{l}\text { Transport Mode } \\
\text { Studied }\end{array}$ & Route Scenario & $\begin{array}{c}\text { Modal Choice Consider- } \\
\text { ations }\end{array}$ & Cargo Attributes \\
\hline $\begin{array}{l}\text { Rodemann and } \\
\text { Templar (2004) }\end{array}$ & Rail, sea, road & $\begin{array}{l}\text { Hamburg - Beijing } \\
\text { Duisburg - Lanzhou }\end{array}$ & $\begin{array}{l}\text { Freight rate per FEU, } \\
\text { transit time, general ena- } \\
\text { blers and inhibitors }\end{array}$ & $\begin{array}{l}\text { General high vs. low- } \\
\text { value cargo }\end{array}$ \\
\hline $\begin{array}{l}\text { Besharati et al. } \\
\text { (2017) }\end{array}$ & Rail, sea & $\begin{array}{l}\text { Different block train } \\
\text { origin-destinations }\end{array}$ & $\begin{array}{l}\text { Freight rate per FEU, } \\
\text { government subsidies }\end{array}$ & $\begin{array}{l}\text { Export goods from EU } \\
\text { that benefit from rail }\end{array}$ \\
\hline $\begin{array}{l}\text { Chen et al. } \\
\text { (2017) }\end{array}$ & Rail, sea & Hefei - Hamburg & $\begin{array}{l}\text { Freight rate per FEU, } \\
\text { transit time, general mode } \\
\text { characteristics }\end{array}$ & N/A \\
\hline Seo et al. (2017) & Rail, sea, air & $\begin{array}{l}\text { Chongqing - Rotter- } \\
\text { dam }\end{array}$ & $\begin{array}{l}\text { Freight rate per FEU, } \\
\text { transit time, and transit } \\
\text { time reliability }\end{array}$ & $\begin{array}{l}\text { Laptops as high-value } \\
\text { good object of case } \\
\text { study }\end{array}$ \\
\hline $\begin{array}{l}\text { Yang et al. } \\
\text { (2017) }\end{array}$ & $\begin{array}{l}\text { Rail, sea, sea/rail via } \\
\text { Piraeus }\end{array}$ & $\begin{array}{l}\text { China - Central and } \\
\text { Eastern Europe }\end{array}$ & $\begin{array}{l}\text { Transport cost of operator } \\
\text { per TEU }\end{array}$ & N/A \\
\hline $\begin{array}{l}\text { Yang et al. } \\
\text { (2018) }\end{array}$ & $\begin{array}{l}\text { Rail, sea, sea/rail via } \\
\text { Piraeus }\end{array}$ & $\begin{array}{l}\text { China- Central and } \\
\text { Eastern Europe }\end{array}$ & $\begin{array}{l}\text { Freight rate per FEU, trip } \\
\text { time and frequency }\end{array}$ & $\begin{array}{l}\text { Cargo value, time sen- } \\
\text { sitivity, fragility }\end{array}$ \\
\hline $\begin{array}{l}\text { Wiegmans and } \\
\text { Janis (2018) }\end{array}$ & Rail, sea & Shanghai - Rotterdam & $\begin{array}{l}\text { Operational, economic, } \\
\text { environmental and social } \\
\text { performance }\end{array}$ & N/A \\
\hline $\begin{array}{l}\text { Jiang et } \\
\text { al.(2018) }\end{array}$ & Rail, sea & $\begin{array}{l}\text { China - EU, different } \\
\text { origin- destinations }\end{array}$ & $\begin{array}{l}\text { Total freight costs per } \\
\text { FEU, government sub- } \\
\text { sidy, transit time }\end{array}$ & $\begin{array}{l}\text { Scenarios of IT prod- } \\
\text { ucts vs. products of } \\
\text { other shippers }\end{array}$ \\
\hline $\begin{array}{l}\text { Jiang et al. } \\
\text { (2019) }\end{array}$ & Rail, sea & $\begin{array}{l}\text { Chongqing/Shanghai - } \\
\text { Hamburg }\end{array}$ & $\begin{array}{l}\text { Freight rate per FEU, } \\
\text { transit time, }\end{array}$ & N/A \\
\hline $\begin{array}{l}\text { Wen et al. } \\
\text { (2019) }\end{array}$ & Rail, sea & $\begin{array}{l}\text { Nanjing/Shanghai - } \\
\text { Hamburg }\end{array}$ & $\begin{array}{l}\text { Costs, transit time, relia- } \\
\text { bility, security, environ- } \\
\text { mental. impact }\end{array}$ & \\
\hline Bucsky (2019) & Rail, sea & China -EU & $\begin{array}{l}\text { Freight rate per TEU, } \\
\text { transit time }\end{array}$ & $\begin{array}{l}\text { Value and weight per } \\
\text { product group }\end{array}$ \\
\hline $\begin{array}{l}\text { Dunmore et al. } \\
\text { (2019) }\end{array}$ & Rail, sea, air & China - EU & $\begin{array}{l}\text { Transport price per unit, } \\
\text { transport time }\end{array}$ & $\begin{array}{l}\text { General high vs. low- } \\
\text { value cargo }\end{array}$ \\
\hline Lu et al. (2019) & Rail, sea & $\begin{array}{l}\text { Beijing/Tianjin - Ber- } \\
\text { lin/Rotterdam }\end{array}$ & $\begin{array}{l}\text { Location of origin-desti- } \\
\text { nation, freight costs, time } \\
\text { costs }\end{array}$ & $\begin{array}{l}\text { Cargo value included } \\
\text { in time cost consi-de- } \\
\text { rations }\end{array}$ \\
\hline $\begin{array}{l}\text { Kundu and Sheu } \\
\text { (2019) }\end{array}$ & Rail, sea & $\begin{array}{l}\text { China - Germany/ } \\
\text { Hamburg }\end{array}$ & $\begin{array}{l}\text { Freight rate per FEU, } \\
\text { government subsidy, } \\
\text { transit time, and mode re- } \\
\text { liability }\end{array}$ & $\begin{array}{l}\text { High- vs low-value } \\
\text { shippers with different } \\
\text { preset service level } \\
\text { preferences }\end{array}$ \\
\hline $\begin{array}{l}\text { Feng et al. } \\
\text { (2019) }\end{array}$ & Rail, sea, air & Wuhan-Hamburg & $\begin{array}{l}\text { Operating costs and } \\
\text { freight rate per FEU, gov- } \\
\text { ernment subsidy, } \\
\text { transport time }\end{array}$ & N/A \\
\hline $\begin{array}{l}\text { Song et al. } \\
\text { (2011) }\end{array}$ & Sea/rail, sea & $\begin{array}{l}\text { Korea / Japan / China - } \\
\text { EU, different routes }\end{array}$ & $\begin{array}{l}\text { Freight rate per FEU, } \\
\text { transit time }\end{array}$ & N/A \\
\hline $\begin{array}{l}\text { Song and } \mathrm{Na} \\
\text { (2012) }\end{array}$ & Sea/rail, sea & $\begin{array}{l}\text { Korea / Japan / China - } \\
\text { EU, different routes }\end{array}$ & $\begin{array}{l}\text { Freight rate per FEU, } \\
\text { transit time }\end{array}$ & N/A \\
\hline Tsuji (2013) & Sea/rail, sea & $\begin{array}{l}\text { Busan - Moscow via } \\
\text { different routes }\end{array}$ & $\begin{array}{l}\text { Freight rate per FEU or } \\
\text { TEU, transit time }\end{array}$ & N/A \\
\hline
\end{tabular}




\begin{tabular}{|l|l|l|l|l|}
\hline $\begin{array}{l}\text { Kim et al. } \\
(2020)\end{array}$ & Sea/rail, sea & Korea - EU via TSR & $\begin{array}{l}\text { Diverse set of strengths, } \\
\text { weaknesses threats and } \\
\text { opportunities }\end{array}$ & N/A \\
\hline $\begin{array}{l}\text { Moon et al. } \\
(2015)\end{array}$ & $\begin{array}{l}\text { Rail, sea/rail, sea } \\
\text { (NSR, SCR) }\end{array}$ & Korea - EU via TSR & $\begin{array}{l}\text { Transport distance, time, } \\
\text { costs, service, safety, } \\
\text { route and mode awareness }\end{array}$ & N/A \\
\hline $\begin{array}{l}\text { Zeng et al. } \\
(2020)\end{array}$ & $\begin{array}{l}\text { Rail, sea (NSR, } \\
\text { SCR) }\end{array}$ & $\begin{array}{l}\text { Shanghai / Shenzhen / } \\
\text { Dalian - Hamburg }\end{array}$ & $\begin{array}{l}\text { Freight rate per FEU, } \\
\text { transit time, safety, con- } \\
\text { venience, frequency }\end{array}$ & $\begin{array}{l}\text { Value of shipper pref- } \\
\text { erence }\end{array}$ \\
\hline
\end{tabular}

Source: Authors' own 